\title{
DNA VARIATION BETWEEN AND WITHIN CHROMOSOME COMPLEMENTS OF VICIA SPECIES
}

\author{
S. N. RAINA* and H. REES \\ Dept. of Agricultural Botany, University College of Wales, Aberystwyth
}

Received 26.xi.82

\begin{abstract}
SUMMARY
$2 C$ nuclear DNA amounts in diploid species of the genus Vicia $(x=5,6$, and 7) range from approximately four to twenty seven picograms. The DNA amount varies independently of the chromosome number and of taxonomic grouping within the genus. Comparisons of the distribution of DNA amounts among chromosomes within the complements show that increase in total nuclear DNA amount within the genus is achieved by equal increments to each chromosome independent of size i.e., small chromosomes acquire the same amount of extra DNA as the large chromosomes. An inevitable consequence of such a pattern of DNA change is that the chromosomes within complements with high DNA amount are more alike in size and DNA content, more symmetrical, than within complements of species with low DNA amount. In a few species the symmetry is confounded as a result of Robertsonian fusion. The equal distribution of extra DNA among chromosomes within a complement has been reported in other genera of flowering plants viz. in Lolium, Festuca and Lathyrus. In all cases there is evidently a severe constraint either upon the way in which the nuclear DNA variation is achieved or else upon its persistence in the face of selection. Since the pattern of change affects the relative sizes of chromosomes within complements we conclude that relative size may itself be of adaptive importance.
\end{abstract}

\section{INTRODUCTION}

The genus Vicia of the family Leguminosae includes about 120 species widely distributed throughout the temperate zones of both hemispheres. Some 40 species, mainly of Eurasian origin, are cultivated (Harlan, 1956).

Fifty three per cent of the species are diploids with a basic number of $x=7$. Thirty three and eight per cent are diploids with $x=6$ and $x=5$ respectively. Only six species are polyploids, about five per cent of the total. All are tetraploids, based either on $x=6$ or $x=7$. Apart from the numerical chromosome variation there is a considerable variation in chromsomome size among species. Not surprisingly, therefore, there is a large scale interspecific variation in nuclear DNA amount (Martin and Shanks, 1966; Rees et al., 1966; Chooi, 1971). The following investigation, which embraces 56 species, was designed to determine the pattern of nuclear DNA variation between the complements of different species and, as well, to determine how the DNA differences between species are distributed among individual chromosomes within complements. The information tells us how chromosome complements diverge in conjunction with speciation. It tells us also how individual chromosomes within complements diverge and evolve relative to one another.

\footnotetext{
* Present address: Department of Botany, The University of Jodhpur, India.
} 


\section{MATERiAl AND METhods}

A list of the species investigated is given in table 1 . The seeds were obtained from Dr C. Lehmann, Zentralinstitut für Genetik und Kulturpflanzen forschung, Gatersleben, to whom we are grateful. We have retained the nomenclature adopted by this Institute. In passing, however, it is important to draw attention to conflicting opinions concerning the taxonomy of Vicia. The sativa complex, for example, has been variously assigned to from one to fourteen separate species (Baker, 1970). According to Plitman (1967) and Ball (1968) the complex was considered to represent one species but with five and six distinctive sub-species respectively. Mettin and Hanelt (1964) and Hanelt and Mettin (1966), on the other hand, consider that these subspecies merit specific status. We fully appreciate that the classification we have adopted may not, therefore, meet with universal approval among taxonomists.

\section{(a) Karyotypes}

Actively growing root tips were immersed in distilled water and kept in an ice box for $24 \mathrm{hrs}$. They were subsequently fixed in freshly prepared $1: 3$ acetic ethanol. Roots were washed in distilled water for 30 minutes, hydrolysed in $5 \mathrm{HNCl}$ for $1 \mathrm{hr}$ at room temperature and stained in Feulgen solution for $1 \mathrm{hr}$ before squashing.

\section{(b) Nuclear DNA estimation}

Seeds, treated with $0.1 \mathrm{HgCl}_{2}$ for 2 mins., were washed thoroughly in distilled water and germinated in an incubator at $24^{\circ} \mathrm{C}$ on filter paper moistened with distilled water. Primary root tips were excised and fixed in ice cold, phosphate buffered 4 per cent Formaldehyde at $p \mathrm{H} \mathrm{7.00} \mathrm{for} 2$ hrs (Teoh and Rees, 1976). They were then thoroughly washed by frequent changes of distilled water for $24 \mathrm{hrs}$. and subsequently fixed in freshly prepared 1:3 acetic ethanol. After washing in distilled water for 30 mins the root tips were hydrolysed in $5 \mathrm{NHCl}$ for one hour at room temperature and stained in Feulgen solution $(p \mathrm{H} 2 \cdot 2)$ for one hour. The stained root tips were washed in three changes of $\mathrm{SO}_{2}$ water for ten minutes each, dried briefly on absorbent paper and finally squashed firmly in a drop of glycerol. The slides were stored at $4^{\circ} \mathrm{C}$ and scored within four days. Photometric measurements were made, using a Vickers M86 with the scan size selector at $1 \times 1$. An average of $352 C$ nuclei were scanned in root meristems in each of three plants in each species. Measurements for each species were accompanied by measurements in root tips of Allium cepa, which acted as a control to take account of experimental variables including any fading of the Feulgen stain. Using the $2 C$ value $(33.5 \mathrm{pg}$ ) as a standard (Bennett and Smith, 1976) absorption values for each of the 56 species were converted to absolute amounts.

\section{(c) DNA amounts within individual chromosomes}

By using an adjustable mask, DNA amounts, in arbitrary units, were obtained for individual chromosomes within a complement by the scanning of well spread Feulgen stained metaphases. Knowing the total nuclear 
DNA amount in picograms from the scanning of interphase nuclei, as described above, arbitrary values for individual chromosomes were readily converted to picograms.

The areas of individual chromosomes were also obtained by scanning with the densitometer. The graphs in fig. 1 show a clear linear relationship between area and DNA content. The data for the two species represented are typical of the 12 species examined. The linear relationship between chromosome area and DNA content is worth emphasising. It means that with knowledge of the total nuclear DNA content in pg. the DNA content of individual chromosomes within a complement may be readily and generally established simply by estimating the areas of the metaphase chrosomes.

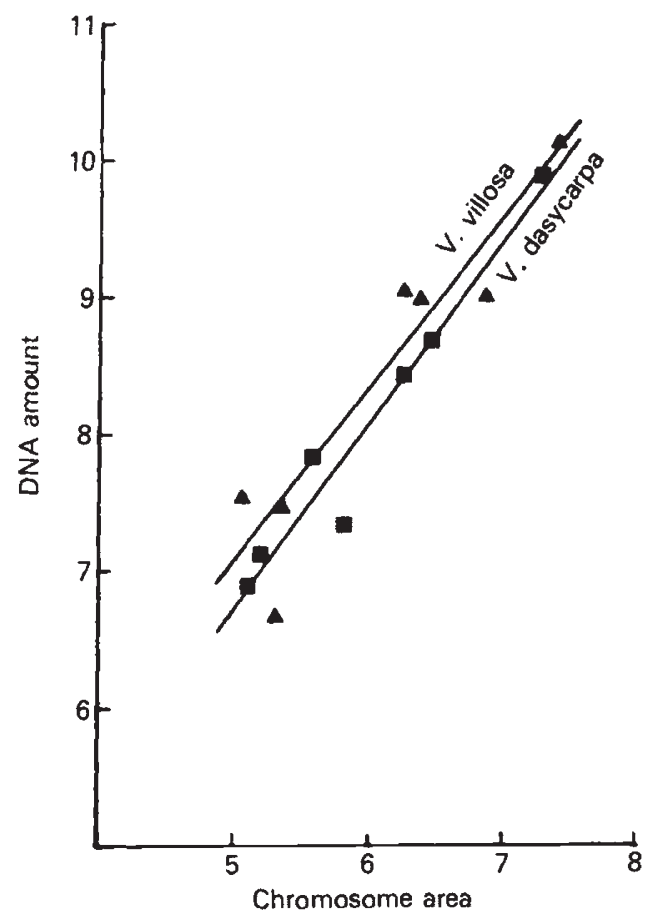

FIG. 1. The mean DNA amounts of individual chromosomes of the complements of Vicia villosa and $V$. dasycarpa plotted against the chromosome areas at metaphase of mitosis. Measurements in arbitrary units.

\section{RESULTS AND ANALYSIS}

(a) Variation between species

In Table 1 are the chromosome numbers and the $2 C$ DNA amounts in the $\mathbf{5 6}$ species investigated. From this table we observe;

(1) That the species fall into three groups in respect of basic chromosome numbers, with $x=5,6$, and 7 .

(2) The large scale variation in nuclear DNA amount, ranging from $3.85 \mathrm{pg}$. in $V$. monantha ssp. triflora to $27.07 \mathrm{pg}$. in $V$. faba. 


\section{TABLE 1}

The $2 C$ nuclear DNA amounts in 56 Vicia species. All are diploids except $V$. cracca and $V$. tenuifolia. " $2 C$ " values for the tetraploids are equivalent to G1 amounts at interphase in somatic cells

\begin{tabular}{|c|c|c|}
\hline Species & $2 n$ & $\begin{array}{c}\text { DNA amount } \\
\text { (picograms) }\end{array}$ \\
\hline \multicolumn{3}{|l|}{ Section Vicia } \\
\hline V. cordata & 10 & 3.95 \\
\hline$V$, sativa con var. sativa var. sativa & 12 & $4 \cdot 50$ \\
\hline V. pilosa & 14 & $4 \cdot 78$ \\
\hline V. angustifolia ssp. segetalis & 12 & 5.06 \\
\hline$V$. angustifolia ssp. angustifolia & 12 & 5.00 \\
\hline$V$. macrocarpa & 12 & $5 \cdot 40$ \\
\hline$V$. lathyroides & 12 & 6.47 \\
\hline V. grandiflora var. kitaibeliana & 14 & $7 \cdot 20$ \\
\hline V. grandiflora var. grandiflora & 14 & 9.05 \\
\hline$V$. pyrenaica & 14 & $8 \cdot 29$ \\
\hline V. ludoviciana & 14 & 8.48 \\
\hline V. incisaeformis & 14 & 8.66 \\
\hline$V$. sepium var. sepium & 14 & 9.34 \\
\hline V. pseudorobus & 14 & 11.53 \\
\hline$V$. pannonica ssp. pannonica & 12 & $13 \cdot 52$ \\
\hline V. hyrcanica & 12 & $15 \cdot 22$ \\
\hline V. hajastana & 10 & 15.66 \\
\hline$V$. hybrida & 12 & 16.46 \\
\hline$V$. lutea & 14 & 18.03 \\
\hline$V$. peregrina & 14 & $19 \cdot 15$ \\
\hline$V$. melanops var. melanops & 10 & $20 \cdot 02$ \\
\hline V. michauxii & 14 & $20 \cdot 68$ \\
\hline \multicolumn{3}{|l|}{ Section Cracca } \\
\hline V. monantha ssp. triflora & 14 & 3.85 \\
\hline V. dasycarpa & 14 & 4.42 \\
\hline V. eriocarpa & 14 & $4 \cdot 50$ \\
\hline V. villosa & 14 & $4 \cdot 67$ \\
\hline$V$. benghalensis & 14 & 6.95 \\
\hline V. atropurpurea & 14 & 7.09 \\
\hline V. biennis & 14 & $7 \cdot 32$ \\
\hline V. elegans & 12 & $8 \cdot 14$ \\
\hline V. incana & 12,13 & $8 \cdot 18$ \\
\hline$V$. dalmatica & 12 & 8.23 \\
\hline V. cassubica & 12 & $8 \cdot 26$ \\
\hline$V$ orobus & 12 & $10 \cdot 60$ \\
\hline$V$. neglecta & 12 & 11.08 \\
\hline V. amurensis & 12 & 11.29 \\
\hline V.cracca var. cracca & 28 & 13.01 \\
\hline \multicolumn{3}{|l|}{ V. cracca var. grossheimii } \\
\hline V. pisiformis & 12 & $14 \cdot 15$ \\
\hline V. articulata & 14 & $14 \cdot 24$ \\
\hline V. tenuifolia & 24 & 15.99 \\
\hline V. sylvatica & 14 & $16 \cdot 14$ \\
\hline V. dumetorum & 14 & $18 \cdot 56$ \\
\hline \multicolumn{3}{|l|}{ Section Ervum } \\
\hline V. palaestina & 14 & $5 \cdot 10$ \\
\hline V. disperma & 14 & $5 \cdot 18$ \\
\hline$V$. tetrasperma & 14 & $7 \cdot 20$ \\
\hline$V$. pubescens & 14 & $7 \cdot 36$ \\
\hline$V$. ervilia & 14 & $8 \cdot 41$ \\
\hline
\end{tabular}




\begin{tabular}{lcc}
\hline \multicolumn{1}{c}{ Species } & $2 n$ & $\begin{array}{c}\text { DNA amount } \\
\text { (picograms) }\end{array}$ \\
\hline V. vicioides & 14 & 8.64 \\
$V$. hirsuta & 14 & 8.95 \\
$V$. graminea & 14 & 13.43 \\
Section Faba & & \\
V. bithynica & 14 & 9.98 \\
$V$. johannis var, johannis & 14 & $14 \cdot 14$ \\
$V$. serratifolia & 14 & 15.63 \\
$V$. narbonensis var. narbonensis & 14 & 16.11 \\
V. faba sep. minor var. minor subvar. minor & 12 & 27.07 \\
\hline
\end{tabular}

(3) DNA amounts are not correlated with chromosome number.

(4) There is no general connection between DNA amount and taxonomic grouping (cf. Seal and Rees, 1983).

As would be expected, the average size of chromosomes increases with increasing nuclear DNA amount (fig. 2). There is, in addition, a marked variation in the relative size and shape of chromosome within the complements of certain species. This is particularly true of species with $x=5$ and 6 (fig. 2). One concludes from this that the divergence and evolution of Vicia species were accompanied not only by the accretion or deletion of DNA but, in some cases, also by chromosomal rearrangement brought about by structural changes. Prominent among these is Robertsonian fusion. It is generally accepted that the "primitive" Vicia complement is $2 x=14$ and that the lower basic numbers were derived as a result of such Robertsonian fusion (Heitz, 1931; Coutinho, 1940; Hirayoshi and Matsumura, 1952). For example, the $V$. faba complement $2 x=12$ includes a pair of large metacentric chromosomes (fig. 2) each derived from the fusion of two acrocentric chromosomes in an ancestral complement of $2 x=14$ (White, 1978). It is probable that pericentric inversions also contributed to the variation in centromere position within chromosomes of different species. We shall return to consider these structural changes, particularly Robertsonian changes, in a later section. In the meantime it is important to stress that change in the distribution as well as in the amount of DNA accompanied the evolution of Vicia species.

\section{(b) Variation within species}

The two varieties of the highly polymorphic species ( $V$. grandiflora) differ markedly in DNA amounts. $2 C$ nuclei of $V$. grandiflora var. grandiflora contain $1.85 \mathrm{pg}$. more DNA than $V$. grandiflora var. kitaibeliana, morphologically a form intermediate between var. grandiflora and var. biebersteiniana (Plitmann, 1967). While from a taxonomic and therefore morphological standpoint the two varieties are sufficiently similar to be classified as members of the one species it is clear that such similarity is achieved despite a large difference in nuclear DNA content. It would be of particular interest to investigate hybrids between these varieties with a view to establishing their fertility and thereby to determine whether in the light of the nuclear DNA difference there is indeed a case for considering the different varieties as different species. 
$V$. cordata $(2 x=10), V$, angustifolia $(2 x=12), V$. macrocarpa $(2 x=12)$ and $V$. pilosa $(2 x=14)$ are considered to be subspecies of $V$. sativa by Plitmann (1967) and Ball (1968) but as separate species by Mettin and Hanelt (1964) and Hanelt and Mettin (1966). The DNA amounts are very different; $3.95 \mathrm{pg}$ in $V$. cordata, $4.78 \mathrm{pg}$. in $V$. pilosa, 5.00 to $5.06 \mathrm{pg}$. in $V$. angustifolia and $5.40 \mathrm{pg}$. in $V$. macrocarpa. On the face of it these are good grounds for supporting the view that they are indeed different species. Good supporting evidence is provided by Mettin and Hallet (1964). In crosses between these forms either the ovules were not fertilized, the seeds did not develop, or else the F1 hybrid plants were sterile.

\section{(c) The distribution of DNA changes between complements}

In Vicia, Martin and Shanks (1966) reported big differences in. DNA amounts between species but, also, reported that the DNA values between groups of species fell into a well defined series viz., 1:3:6. In the present and much more extensive investigation there is no evidence of such a marked discontinuity between groups or of such a pronounced series as that reported by Martin and Shanks (see also Chooi, 1971).

\section{(d) The distribution of DNA changes within complements}

The massive variation in DNA amount between complements which have been described are, to a large degree, independent of chromosome number. In other words the nuclear DNA differences are in the main attributable to the amplification, or possibly deletion, of DNA sequences within chromosomes of the complement. For this reason it is not surprising that chromosome size, reflecting chromosomal DNA content, varies between species (fig. 2). In general, species with high nuclear DNA amounts have larger chromosomes than species with low DNA amounts. By way of illustration (see table 2) the largest chromosome of $V$. faba contains twice as much DNA (7.98 pg.) than the whole chromosome complement of $V$. monantha ssp. triflora $(3.85 \mathrm{pg}$.). There is also a substantial variation in chromosome size and DNA content within complements. The nature of

TABLE 2

The mean DNA amounts (in picograms) of individual metaphase chromosomes (in increasing order of size) in 12 Vicia species

\begin{tabular}{lccccccc}
\hline & 1 & 2 & 3 & 4 & 5 & 6 & 7 \\
$V$. cordata & 0.673 & 0.763 & 0.816 & 0.829 & 0.867 & & \\
$V$. hajastana & 2.330 & 2.477 & 2.519 & 3.642 & 4.690 & & \\
$V$. melanops & 3.177 & 3.247 & 3.634 & 3.926 & 6.037 & & \\
$V$. incana & 1.121 & 1.168 & 1.234 & 1.249 & 1.289 & 2.116 & \\
$V$. hyrcanica & 2.284 & 2.305 & 2.369 & 2.517 & 2.574 & 3.175 & \\
$V$. faba & 3.392 & 3.752 & 3.938 & 3.972 & 4.033 & 7.985 & \\
$V$. dasycarpa & 0.542 & 0.558 & 0.576 & 0.616 & 0.665 & 0.684 & 0.778 \\
$V$. villosa & 0.530 & 0.594 & 0.599 & 0.713 & 0.717 & 0.717 & 0.803 \\
$V$. disperma & 0.605 & 0.669 & 0.684 & 0.734 & 0.745 & 0.851 & 0.896 \\
$V$. hirsuta & 1.090 & 1.106 & 1.246 & 1.256 & 1.331 & 1.388 & 1.534 \\
$V$. bithynica & 1.232 & 1.234 & 1.338 & 1.393 & 1.419 & 1.615 & 1.748 \\
$V$. lutea & 2.476 & 2.496 & 2.523 & 2.590 & 2.607 & 2.652 & 2.684 \\
\hline
\end{tabular}




\section{011 II II II}
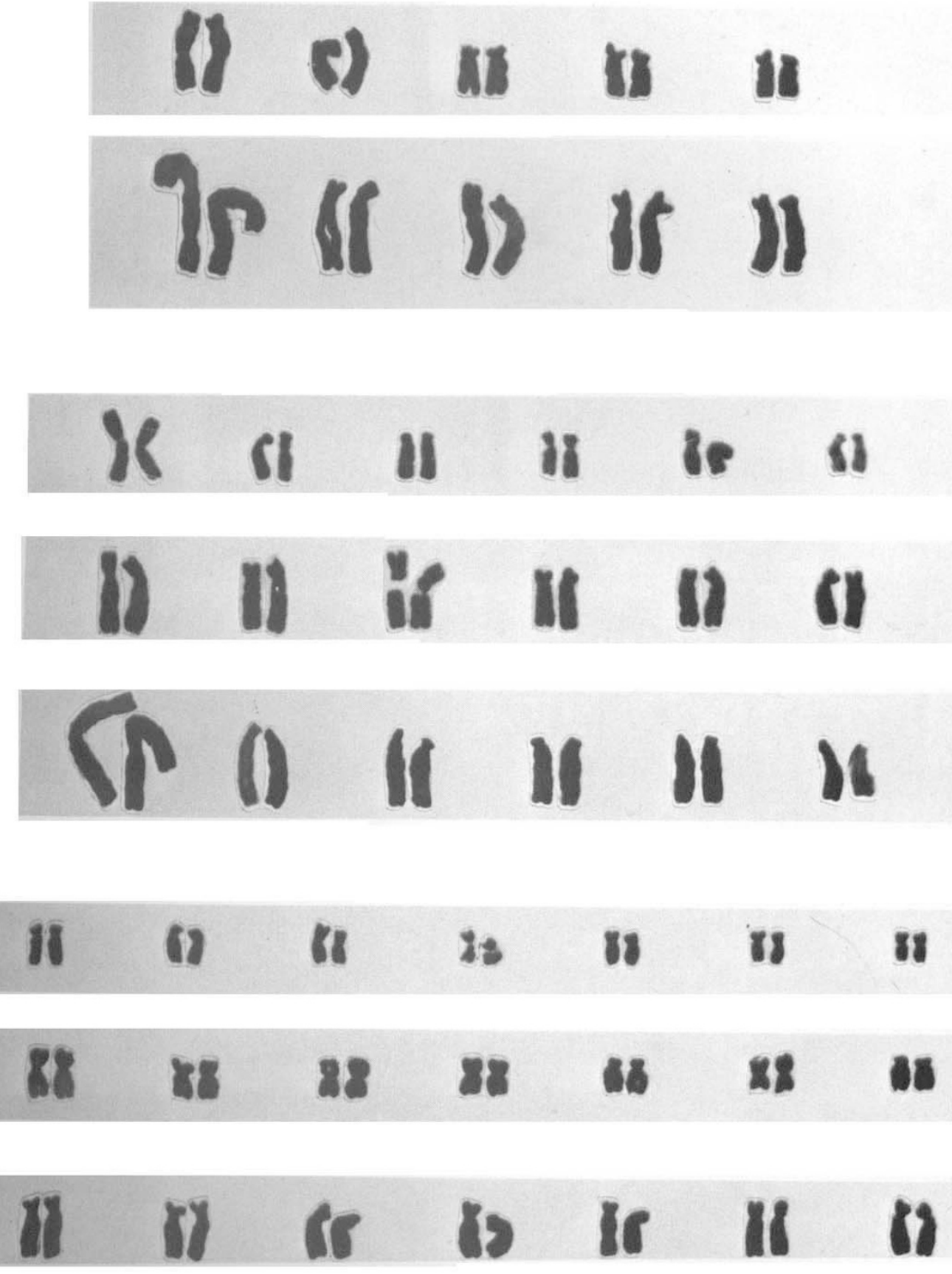

FIG. 2. The chromosome complements of Vicia cordata, $V$. hajastana and $V$. melanoplus, each with $x=5 ; V$. incana, $V$. hyrcanica and $V$. faba $(x=6) ; V$. dasycarpa, $V$. hirsuta and $V$. lutea $(x=7)$. The horizontal bar represents $10 \mu$. 
this variation provides information about the distribution of the quantitative changes within chromosomes that accompanied divergence and evolution within the genus.

\section{(e) Possibilities}

Suppose that the 2C DNA contents of related diploid species are 6 and $12 \mathrm{pg}$ respectively. Suppose, also, that each species is $x=6$ with chromosomes of varying sizes. Two obvious alternatives by which the DNA difference is achieved are,

(i) each chromosome within the complement of the high DNA species has twice as much DNA as its homoeologue in the low DNA species. The larger chromosomes in the high DNA species will consequently carry more extra DNA than the smaller chromosomes.

(ii) each chromosome in the high DNA species has exactly the same amount of extra DNA, viz. $1 \mathrm{pg}$.

Given that the chromosomes within complements are of varying size and DNA content the consequences of (i) and (ii) above would be distinguishable graphically as shown in fig. 3. If (i) applies the regression slopes will diverge. If (ii) the regression siopes will be parallel.

Before considering the distribution of chromosome sizes and DNA content within our Vicia complements it is worth mentioning that in Festuca

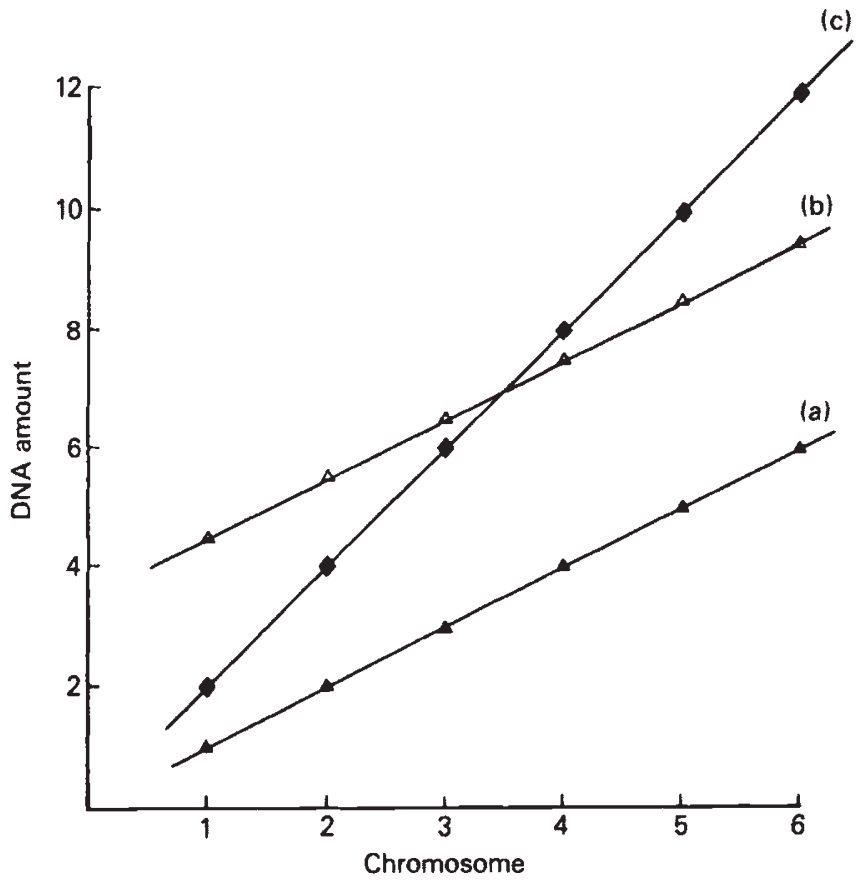

FIG. 3. (b) gives the distribution of DNA amounts expected in individual chromosomes assuming equal increments for each chromosome relative to $(a)$. (c) gives the distribution of DNA amounts assuming that the increase is proportional to the DNA amounts in $(a)$. 
and Lolium the evidence indicates that the DNA changes are distributed equally among all members of the complement (Seal and Rees, 1983), as in (ii) above. The same is true of Lathyrus (Narayan, 1982). Does the same apply to Vicia species?

For the purpose of comparison the chromosomes of each haploid complement have been numbered in increasing order of size (table 2). It is assumed, also, that rank in order of size corresponds with rank in order of homology, namely that chromosomes 1,2 etc. in one species are homologous, or rather homeologous, with chromosomes 1, 2 etc. in other species. Results from other plant genera, e.g., Lolium and Festuca (Seal and Rees, 1983) show that this assumption is reasonable and it is on this basis that the amounts of DNA in the homeologous chromosomes have been plotted for each species with $x=5, x=6$, and $x=7$ (fig. 4). The

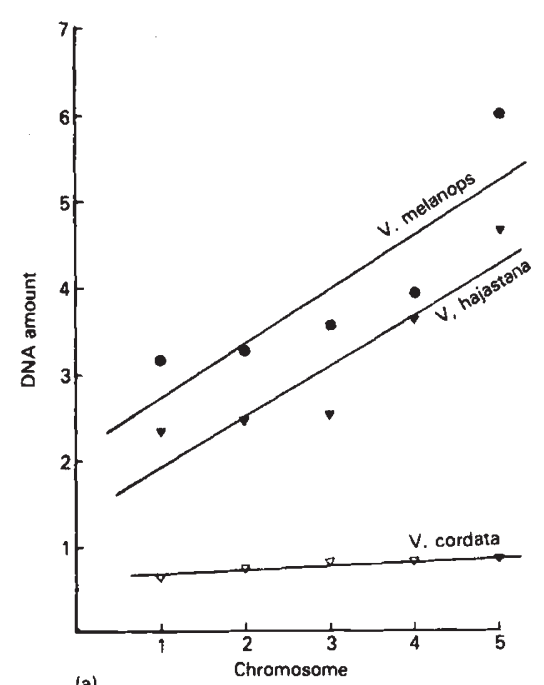

(a)

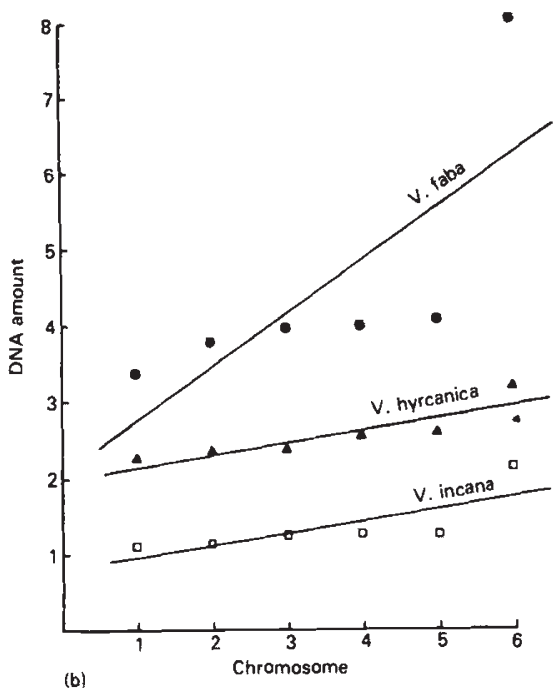

(b)

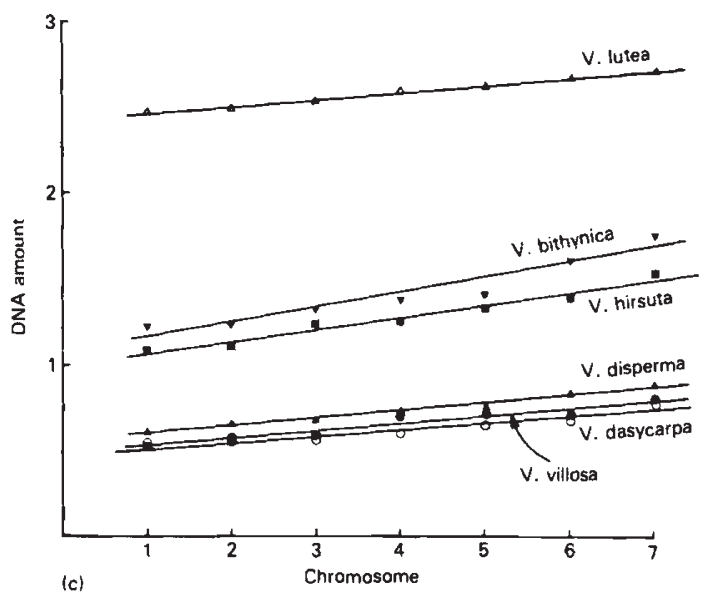

FIG. 4. The mean DNA amounts in pg. in chromosomes of the haploid complements of Vicia species with $x=5(a), x=6(b)$, and $x=7(c)$. The DNA amounts are plotted in increasing order, from 1 to 5,6 and 7 . 
graphs show that for species with $x=5$ and $x=6$ the regression lines for the different complements are certainly not parallel. Their slopes diverge very considerably and significantly. On the face of it the increase in DNA among Vicia species is not, as in Lolium and Festuca, or in Lathyrus (Narayan, 1982), due to the addition of equal amounts added to each chromosome within the complement. Had this been the case we should have expected parallel regression lines (see fig. 3). As will be shown, however, the distinction between Vicia and the other genera is more apparent than real.

\section{(f) A correction for Robertsonian fusion}

Fig. 2 shows that one of the six pairs of chromosomes of Vicia faba is metacentric and twice the size of the remaining five pairs of acroentrics. As already mentioned there is good evidence to indicate that each of the large metacentrics is derived from the fusion of two acrocentrics (cf. White, 1978). $V$. faba therefore is basically a species with $x=7$, reduced to 6 by fusion. There is a case therefore for allocating this species to the $x=7$ group, treating the metacentric as two chromosomes each with half the DNA amount. On precisely the same grounds and in the same manner $V$. incana with $x=6$ and with a pair of metacentrics like $V$. faba is allocated to the $x=7$ group and $V$. melanops and $V$. hajastana each with $x=5$ and with a pair of large metacentrics are shifted to the $x=6$ group (see fig. 2). The regressions for the new groups are given in fig. 5 . We find a startling alteration. The regression lines are now almost exactly parallel and there is no significant heterogeneity in slopes. The results conform precisely with expectation of an equal allocation of additional DNA within each chromosome with increase in total nuclear DNA amount.

\section{CONCLUSION}

In Vicia as in many other genera of flowering plants we have seen that speciation was accompanied by massive changes in chromosome size and DNA amount. After making allowance for changes resulting from Robertsonian fusion we conclude from the evidence presented that the accretion (or diminution) of chromosomal DNA by the amplification (or deletion) of base sequences within each complement affected each chromosome to the same degree. This is despite the fact that there is a considerable variation in size between chromosomes within the Vicia complements. A similar pattern of DNA change is associated with the divergence and evolution of species in Lolium and Festuca (Seal and Rees, 1983) and in Lathyrus (Narayan, 1982). The indications are that the pattern may be widespread among genera of flowering plants. The phenomenon is surprising. One would expect the mutational events leading to the amplification or the deletion of DNA base sequences to affect the DNA molecules at random. One would expect, in consequence, that the accretion or diminution of DNA among chromosomes within a complement would be proportional to chromosome size and DNA content. That this is not the case we can atribute to one of two alternative causes. The first is that there is within each chromosome, independently of size, an equivalent amount of DNA prone to amplification or deletion. Such an explanation is unsatisfactory if 


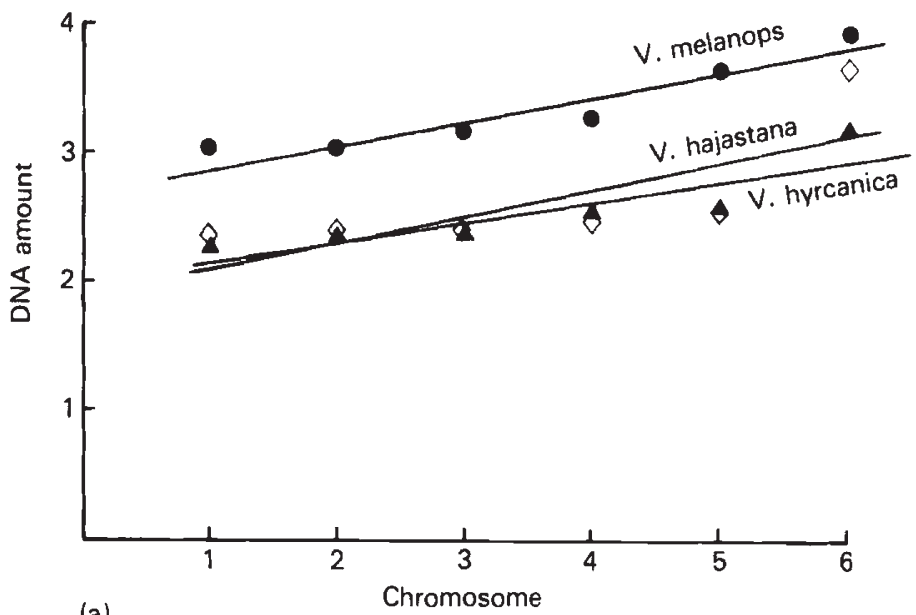

(a)

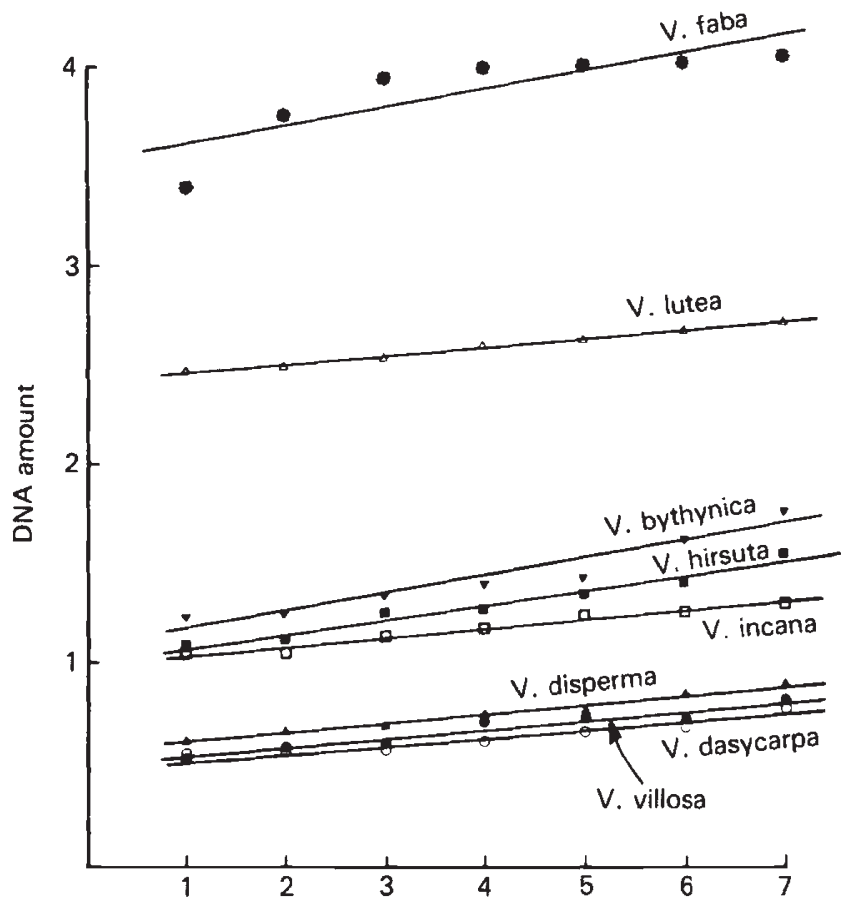

(b)

FIG. 5. The mean DNA amounts in pg. of chromosomes of Vicia species in which DNA amounts in large metacentrics in $V$. melanops and $V$. hajastana $(a), V$. faba and $V$. incana $(b)$ are allocated to two separate chromosomes. DNA amounts in increasing order, from 1 to 6 and 1 to 7 . 
only because it leaves us with much the same problem in a different context, namely how to account for an equal distribution of such "mutation-prone" DNA among chromosomes of different size. It is, moreover, difficult to conceive what kinds of DNA sequences could be involved. The second alternative relates not to the initiation of DNA change by amplification or deletion but to events subsequent to their initiation. We assume that the amplification or deletion occurs at random and is therefore in proportion to chromosome size. We propose that there is, however, a constraint upon the kinds of change that would survive, to the effect that only complements in which there is an equal change in DNA amount within each chromosome persist. This argues of course for selection and, in turn, that the relative size of chromosomes within a complement is in some way of adaptive significance (Mizuno and Macgregor, 1974; Bennett, 1982; Seal and Rees, 1983).

Where an increase in total nuclear DNA is achieved by equal increments to all chromosomes an inevitable consequence would be that the relative differences in chromosome size within the complements would diminish, the complements would become more "symmetrical" (Seal and Rees, loc. cit.). (Such a progression might of course become confounded, as in some of the Vicia species, by gross structural change such as Robertsonian fusion.) A survey of chromosome complements over a range of genera would tell us whether, as we have surmised, this pattern is widespread among flowering plants. Brandham's work on Aloes (1983) tells us that it is not universal. Increasing nuclear DNA in this genus is achieved by a disproportionate amplification of DNA sequences in the larger chromosomes of complements. Yet even here there is again a well defined and rigid pattern of change. The constraint upon the distribution of change, although different from that in Vicia, Lolium, Festuca and in Lathyrus, is no less pronounced. It is difficult to conceive that such constraints and their consequences upon chromosome shapes and sizes are fortuitous.

\section{REFERENCES}

BAKER, H. G. 1970. Genetic resources in plants: their exploration and conservation. In Frankel O. H. and Bennett E. (eds.) Taxonomy and the biological species concept in cultivated plants. Blackwell Scientific Publications, Oxford, pp. 49-68.

BALL, P. W. 1968. Flora Europae 2, Edited by T. G. Tutin et al. Cambridge University Press, London, 128-136.

BENNETT, M. D. 1982. Nucleotypic basis of spatial ordering of chromosomes in eukaryotes and the implications of the order for genome evolution and phenotypic variation. Genome Evolution. Academic Press, London, pp. 239-261.

BENNETT, M. D. AND SMITH, J. B. 1976. Nuclear DNA amounts in angiosperms. Phil. Trans. Roy. Soc. B, 274, 227-274.

BrandhaM, P. E. 1983. Proceedings of the Kew Chromosome Conference 11, Allen and Unwin.

CHOOI, W. Y. 1971. Variation in nuclear DNA content in the genus Vicia. Genetics 68, 195-211.

ChOutinho, L. A. 1940. Racas cariologicas na V. sativa. L. Agron. Lus. 2, 379-403

HANELT, P. AND METTIN, D. 1966. Cytosystematische Untersuchungen in der Artengruppe um Vicia sativa L. II. Kulturpflanze 14, 137-161.

HARLAN, J. R. 1956. Theory and dynamics of grassland agriculture. D. Van Nostrand Co. Inc., Princeton.

HEITZ, E. 1931. Nukleolen und Chromosomen in der Gattung Vicia. Planta 15, 495-505. 
HIRAYOSHI, I. AND MATSUMURA, M. 1952. Cytogenetical studies on forage plants. I. Chromosome behaviour and fertility in $\mathrm{F}_{1}$ hybrids, common vetch $\times$ karasunoendo (native wild vetch in Japan). Jap. J. Breed. 1, 219-222.

MARTIN, P. G. AND SHANKS, R. 1966. Does Vicia faba have multistranded chromosomes? Nature 211,650-651.

METTIN, D. AND HANELT, P. 1964. Cytosystematische Untersuchungen in der Artengruppe um Vicia sativa. I. Kulturpflanze 12, 163-225.

MIZUNO, S. AND MACGREGOR, H. C. 1974. Chromosomes, DNA sequences, and evolution in Salamanders of the Genus Plethodon. Chromosoma, 48, 239-296.

NARAYAN, R. K. J. 1982. Discontinuous DNA variation in the evolution of plant species. The genus Lathyrus. Evolution, 36, 877-891.

PLITMAN, U. 1967. Biosystematical study of Vicia of the middle east. Private Publications, $1-128$.

REES, H., CAMERON, F. M., HAZARIKA, M. H. AND JONES, G. H. 1966. Nuclear variation between diploid angiosperms. Nature, 211, 828-830.

SEAL, A. AND REES, H. 1982. The distribution of quantitative DNA changes associated with the evolution of diploid Festuceae. Heredity, 47, 179-190.

TEOH, S. B. AND REES, H. 1976. Nuclear DNA amounts in population of Picea and Pinus species. Heredity, 36, 123-137.

White, M. J. D. 1978. Modes of speciation. W. H. Freeman and Company, San Francisco. 